\title{
Female Directors, Family Ownership and Firm Performance in Jordan
}

\author{
Zaid Saidat ${ }^{1}$, Claire Seaman ${ }^{2}$, Mauricio Silva ${ }^{2}$, Lara Al-Haddad ${ }^{3} \&$ Zyad Marashdeh $^{4}$ \\ ${ }^{1}$ Department of Accounting and Finance, Middle East University, Amman, Jordan \\ ${ }^{2}$ Department of Business, Enterprise and Management, Queen Margaret University, Edinburgh, United Kingdom \\ ${ }^{3}$ Department of Finance and Banking Sciences, Yarmouk University, Irbid, Jordan \\ ${ }^{4}$ Department of Finance and Banking, The Hashemite University, Zarqa, Jordan \\ Correrspondence: Zaid Saidat, Department of Accounting and Finance, Middle East University, Amman, Jordan.
}

Received: October 4, 2019

doi:10.5430/ijfr.v11n1p206
Accepted: November 5, 2019

Online Published: November 6, 2019

URL: https://doi.org/10.5430/ijfr.v11n1p206

\begin{abstract}
This study examines the impact of female directors on the financial performance of family and non-family Jordanian firms. A sample of 103 Jordanian public firms listed on Amman Stock Exchange for the time period 2009-2015 was selected. The study had a quantitative approach and used a panel data methodology. The data analysis was conducted using Ordinary Least Square Regression. ROA and Tobin's Q were deployed as measurement of financial performance. The appointment of female directors does not have any significant impact on the financial performance of family firms. However, with regard to non-family firms, female directors appeared to have a negative impact on the performance of these firms. The impact of female directors on family firm performance merits further research in the context of different countries and cultures. Appointments based on qualifications and expertise is more likely to have a positive impact. Jordan is an under-researched area where the impact of female directors on the firm performance would merit further research. Differentiating between the impact of female directors on family and non-family firms would also merit further research, especially in the context of the conditions under which they are appointed.
\end{abstract}

Keywords: family firms, female directors, firm performance, Jordan, non-family firms

\section{Introduction}

Boards play an important role in ensuring compliance with corporate governance practices in general, and in monitoring and advising the top management in particular. Earlier work (e.g. Pandya, 2011; Bonn, Yoshikawa and Phan, 2004) have focused on the characteristics of board to ensure that the board attains its goals towards achieving the company success (Al-Matari et al., 2012). Different board characteristics could impact the firm performance, including board diversity such as gender (e.g., Ferreira, 2015; Parola et al. 2015). According to Hillman et al. (2002) the diversity of board gender may lead to the formation of a diverse team of skills, professionals and knowledge, and thus the board of directors has greater capacity to fulfill responsibilities for following up the interests of shareholders. Reports show that the percentage of female members on the board has increased over time in countries such as the USA and UK, but remains much lower than the percentage of men (WEU, 2002; USDOL, 2005). In spite of the large number of studies on this topic, the question on the effects of female directors on the firm performance is ongoing. Nowadays, gender diversity on corporate board has attracted the attention of both scholars and regulators. In particular, the UK Corporate Governance Code 2014 provides that "One of the ways in which constructive debate can be encouraged is through having sufficient diversity on the board... Diversity is as much about differences of approach and experience, and it is very important in ensuring effective engagement with key stakeholders and in order to deliver the business strategy" (p.2).

Women's presence in corporate boards has been increasing in most countries around the world over the last two decades. According to World Bank Group (2015), the percentage of female on top positions in developed countries is 23 percent and may reach to 30 percent in other countries like Philippines. This is may be due to the Companies Act in these countries. For example, Norwegian companies were required by law to employ women to at least 40 per cent of board size (Smith et al., 2006), since 2010 the Finnish government has required companies to have at least one female on the board. French lawmakers had been working since 2006 on a law that provides quotas for women on boards. In 2011, the law was approved and states that the public companies should fill at least $40 \%$ of their board by 
female directors since 2016 (Nekhili and Gatfaoui, 2013). In Germany, Law requiring at least 30\% of board members at large companies to be female from 2016 (Dauer, 2014).

Unlike its counterparts in the European Union, The UK government has made recommendations rather than imposing mandatory laws on gender diversity for board level positions. The Davies report (2012) recommends 25\% female representation on the boards of FTSE 100 companies by 2015. Recently, the figures show that female directorships in FTSE companies have risen from 12\% in 2011 to 25\% in 2014 (Stern, 2014). Overall, the number of women on boards across Europe rose to 23\% in 2016 from 11\% in 2007 (European Commission, 2016). It indicates that gender diversity is a sensitive mechanism that can leads to better governance and firm performance (Davies Report, 2012).

In case of Jordan, a report of IFC (2011) shows that among 237 public listed companies in 2012, only 52 firms have women on their board, which means that about of companies have women in their boards. Female representation on the Boards of Jordanian companies is therefore quite small, which may in turn be related to cultural factors that deter the inclusion of women from corporate boards. For example, a study conducted by Scheme (2013) point out that corporate culture in Jordan appears to limit the growth, development, and advancement of women. However, a significant number of companies in Jordan are characterised by concentrated ownership, dominated by the family. Therefore, family female members usually participate in the management of a firm by holding positions such as chairman of the board of directors and/or senior executive.

\subsection{Statement of the Problem}

Empirical evidence about the relationship between female members and firm performance are inconsistent and somewhat inconclusive, especially in developed countries, such as the US, the UK and some European countries. Similarly, empirical studies in emerging countries including Jordan are limited and sparse. However, some researchers have empirically supported the value of female directors on a board in terms of problem solving capabilities, innovation and creativity that improve firm performance (Carter et al., 2003; Erhardt et al., 2003 in the U.S.; Smith et al., 2006 in Denmark; Nguyen and Faff, 2007 in Australia; Francoeur et al. 2008 in Canada; Martín-Ugedo and Antonio, 2014 in Spain). In parallel, some researchers have argued that where the diversity of a board increases to include female directors, communication and cooperation between male directors tends to decrease (Adams and Ferreira, 2009 in the U.S.; Shehata et al., 2017 in the UK). However, this relationship has not been considered in Jordan, where different cultural factors may influence the impact of female directors.

Moreover, the existing literature has only studied to a limited degree the impact of female board members on family firm performance (Amore et al., 2014 in Denmark; Menozzi et al., 2015 in Italy; Sarkar and Selarka, 2015 in Indian), acknowledging that the relationship between female directors and performance for family and non-family firms is an open question that is need to be investigated further in order to explain the direction of ambiguous relationship between the female directors and performance of family firms compared to non-family firms. As mentioned earlier, many of companies in Jordan, dominated by the family, where the founder and/or family members usually possess a great many shares of the company and often have a significant impact on the management of the company's operations. Thus, the women who become directors tend to come from powerful families. Founders are appointing their wives, daughters and sisters in director positions to play an important role in the future of the business. According to Moore et al. (2005) working in an environment dominated by females, and with a female supervisor will increase levels of social support, functional independence, and lower levels of depression and family conflict at work. Further, they argue that women family members' skills and experiences effectively complement the owner-manager's expertise (Moore et al., 2005).

This paper sets out, therefore, to examine the effects of appointing females in the boardroom on firm performance in Jordan. To the best of our knowledge, this is the first study in Jordan that tried to examine the relationship between firm performance and females' presentation in boardroom, as well as the first to differentiate between their impact on family and non-family Jordanian firms. Accordingly, in this study, we investigate this relation using a sample of 103 companies listed on Amman Stock Exchange (ASE) selected from the service and industrial sectors for the period that ranging from 2009 to 2015.

\subsection{Objective of the Study}

This study aims to analyse the impact of gender diversity with Boards of Directors on firm performance in Jordan by:

i. To investigate the impact of female board member on the financial performance of firms listed in Amman Stock Exchange.

ii. To investigate if the impact of female board member on family firms differ from their non-family counterparts 
in Jordan.

\section{Literature Review and Hypotheses Development}

The Board of directors plays a key role in ensuring the effective monitoring over top management through reducing agency costs and advising and guide managers toward achieving the company's success (Brennan, 2006). Therefore, the participation of the board of directors is a vital part of corporate success. According to Nicholson \& Kiel (2007) the corporate board should not only be involved in a monitoring role, but also work to provide critically needed resources, such as establishing business connections and contracts, and providing advice to managers. Consequently, the board of directors is a key link between the corporation and financial and non-financial resources, which are crucial to corporate performance (Pfeffer, 1972; Pearce \& Zahra, 1992). The director offers these resources through their channels with external firms or obtaining information from important authorities outside the firm (Corbetta \& Salvato, 2004). Thus, enhancing the financial performance of the firm, maximizing the shareholders' wealth and assisting in its survival (Pearce \& Zahra, 1992; Sing et al., 1986).

\subsection{Female Board Member and Firm Performance}

Female members on the board are expected to be a source of competitive advantage (Cox and Blake, 1991) as a result of a positive influence on corporate performance by solving problems (Rose, 2007), and increase resources like; innovation and creativity (Carter et al., 2003). Further, women directors may also increase the company's ability to enter markets since they bring more legitimacy to companies and improve the image of the company, as well as expand the company's understanding of the market (Campbell and Minguez-Vera, 2008). Daily, Certo, and Dalton (1999) show that $60 \%$ of all purchases in the US were purchased by women. Based on this, Daily, Certo, and Dalton suggest that, for an effective board of directors, a female director must be appointed, because female member is a sensitive monitor of the market and can take a more realistic approach that can reflect the consumer's point of view. In this way, there might be a significant impact on the company's performance and shareholder value (Smith et al., 2006). In this context, a report by Catalyst (2004) using a sample of 353 Fortune 500 firms over the period 1996 to 2000 , show that a higher percentage of women on the board attained better performance compared to the firms with a smaller representation of women on the board.

Adams and Ferreira (2009) argue that the existence of a female on the board has a positive influence on the board effectiveness through board meeting attendance, involve in monitoring committees, and the sensitivity CEO turnover to performance. Consistently, Ahern and Dittmar (2012) reported that employing woman directors can limit CEOs' effect on the boards, and thus reduces the agency costs. Nielsen and Huse (2010) suggest that the female directors can affect the decision-making culture and the structure of the board, through a high level of development activities, open discussion, and reduce the conflict among board members. Post and Byron (2015) suggested similar benefits of the presence of female directors. They were claimed to not only improve corporate performance through more effective decision-making, but also contribute to gaining legitimacy in the eyes of investors. In general, they conclude that the presence of female on the boards made a good atmosphere.

Under the agency theory responsibilities, Carter et al. (2003) state that female director's represent outside directors. This view is supported by Francoeur et al. (2008), they point out that "female (like external shareholders, ethnic minorities, and foreigners) often bring a fresh perspective on complex issues, and this can help correct informational biases in strategy formulation and problem solving”. Similarly, Reguera-Alvarado et al. (2017) stated that a highly diversity board could serve as a governance mechanism, since a broader range of views could increase the board independence. Consistent with Adams and Ferreira (2009), suggested that since female board members did not belong to the "old boys club", they could more closely correspond to the concept of the independent director that has been theoretically confirmed.

According to Huse (2007), female members are more involved in playing a vital role in the board compared to their male colleagues. In addition, some scholars argue that female board members are more likely to discussion issues (Luoma and Goodstein, 1999), asking questions (Burgess and Tharenou, 2002), demonstrate participatory leadership and teamwork skills (Bilimoria, 2006), and support their companies to reach the highest ethical standards (Williams, 2003). Bear et al. (2010) supported the argument, point that with the presence of female directors, communication barriers had been dropped and the voice of the minority had become more assertive.

Previous studies have shown that female board members are better in monitoring the management team and in evaluating their works (Nielsen and Huse 2010; Srindhi et al. 2011). Further, they are more efficient and transparent in providing information to all company managers and shareholders (Alves et al, 2015). From an agency theory perspective, the higher level on monitoring and transparency of information leads to better firm performance. 
From the viewpoint of resource dependency, the source of corporate competitive advantage could be tangible and intangible resources such as human resources, skills and networks that can add a real value to the firm (Barney, 1991). Supporters of resource dependence view emphasizes that there is a strong relationship between such resources and business performance (Harrison and Leitch, 1996; Hillman and Dalziel, 2003). According to Arfken et al. (2004), the female member usually adds complementary skills and new ideas, which makes the board more effective via better board decisions including more participative discussions. In addition to that, Ibarra (1993) state that women directors have more diverse networks compared to male directors. Arfken et al. (2004) asserts that female directors have better knowledge on certain market and consumers than their male counterparts. Finally, female directors generally have a greater impact on the working style and board procedures that can have beneficial influence on performance results (Daily and Dalton, 1994).

Contrary to previous that indicated that women member on boards had a positive effect, there was studies that indicated that the presence of female had negative effect. For example, board members normally include men exhibiting different leadership behaviours (Fenwick and Neal, 2001). Thus, the existence of female members may (in certain cultures) limit communication and cooperation among team members (Torchia, Calabrò and Michèle, 2015). Such situations could be more time-consuming and provoke conflicts (Rose, 2007), in particular when the company is working in a very competitive situation where the ability to communicate and promptly respond to change is an important matter (Smith et al., 2006).

\subsection{Female Board Member and Family Firm Performance}

The empirical assessment of female directors in family businesses is relatively new, and the results are still unclear and need further investigations. Certainly, family firms are interesting and worthy of a thorough investigation by researchers because of their distinctive qualities and characteristics. Stern (2009) indicates that some of these qualities in family businesses may give them an edge over "normal" public firm. McVey and Draho (2005) suggest that underlying this, is that family companies are the result of combining two very different entities, namely the family and the business. As a consequence, family firms have their own specificities related to their culture and values, which play a vital part in shaping a firm's behaviour and corporate decision-making processes. For instance, the family's generational vision of survival and the family participation in the establishment of the business drives family to keep control and deliver the company over to the next generation, rather than viewing the company as a product to consume during its life time. As a result of a family's vision towards survival, family firms are more likely to enhance long-term performance at the expense of short-term returns, since focus on short-term profits could hinder the ultimate goal of the family, which is deliver the company over to the next generations (Anderson and Reeb, 2003). This perspective directs family owners to employing their male and female heirs in director positions better monitoring of management.

One of the issues that must be considered is how the female directors affect the family firm performance and operation (Songini and Gnan, 2015; Jimaneze, 2009). However, Adams and Ferreira (2009) found that the existence of female board members improve monitoring and decreases the agency problems in the companies. Nevertheless, this influence could be either positive or negative depending on their experiences, expertise, and independence. In context of family firms, Ruigrok et al. (2007) found a significant relationship between gender diversity and family firms. They argue that females are usually nominated as directors on the basis of family ties. Thus, she serves as observers and family agents in the company. Salganicoff (1990) stated that women directors provide a unique contribution to management in family firms. Her conclusion further indicates that females have unique behaviors toward family business such as loyalty, caring for family members, and sensitivity to satisfy the other needs. The reason behind this conclusion is based on the study by Belenky (1986) and Gilligan (1982), who argue that females are concentrated in caring and peacekeeping behaviors. In addition, Cole (1997) report that woman in general is feeling more happy to be work in family firms for women working in nonfamily firms. Cromie and O'Sullivan (1999) state that family females prefer to develop their career in family firms rather than outside. Furthermore, Moore et al. (2005) believes that working in an environment dominated by more females, and with a female supervisor will increase the level of social support, functional independence, less depression at work and lower level of family conflict. Further, they argue that women family members' skills and experiences effectively complement the owner-manager's expertise (Moore et al., 2005). Schwartz (1992) found that women directors are more appropriate for overcoming different forms of conflicts inside family firms, including the conflict with minority shareholders' interests, in this manner females contributing positively to performance. Additionally, resource dependency academics suggest that women directors facilitate access to vital resources for the company (Pfeffer, 1972). Eventually, women family members have valuable business networks and professional skills can positively affect family firm performance. 


\subsection{Hypothesis Development}

Empirically, the presence of female members and corporate performance reached mixed results. For instance, using a sample of 500 Canadian companies from 2001 to 2004, Francoeur et al. (2008) investigate the impact of female directors on the abnormal returns for companies operating in complex environments. They found that higher percentage of female directors on the board has a significant positive effect on abnormal returns approximately $0.17 \%$ monthly. They argue that gender diversity leads to more knowledge sources and diverse views that are desirable to develop and provide suggestion to difficult problems. Similarly, Anderson et al. (2011) state that board diversity comprises female member has beneficial effects on the performance of complex companies but has a negative impact on the performance of less complex companies. Smith et al. (2006) studied the impact of women in top management on firm performance, using a sample of 2500 largest Danish firms during the period 1993-2001, and also found that the presence of female on boards of directors and among top management team can have a significant positive influence on performance in particular if female have higher education qualifications. Consistent with earlier studies, Nguyen and Faff (2007) studied the impact of gender diversity on market performance measure, using a sample of the 500 largest firms listed on the Australian Stock Exchange for the period 2000 and 2001, and found a positive association between gender diversity on the boards and Tobin's Q. They point out that female member play a key role in keeping up with the board's effectiveness. Vafaei et al. (2012) confirmed these findings, using a sample period between the year 2005 and 2010 and found a positive relationship between gender diversity on the boards and Tobin's Q and ROA. In Spain, Martín-Ugedo and Antonio (2014) also found a positive relationship between the percentages of female directors, weather high or low and firm value. In a recent study by Green and Homroy (2018) using a sample of 152 firms drawn from 11 western countries during the period 2004 to 2013, and found that the presence of women on corporate boards is linked to improving the company's performance, in particular when female director is appointed to the main decision-making committees.

These prior studies in Australia, Canada and western countries agree with previous studies in the US. For example, Carter et al. (2003) and Erhardt et al. (2003) investigated the correlation between the board diversity (gender) and firm performance using a sample of 638 US firms and 112 US firms respectively, and further found that the presence of female members on boards positively impact firm performance, particularly ROA, ROI and Tobin's Q. Both have argued that US companies with higher proportion of female members on their board increase the effectiveness in monitoring and control function.

In a recent study by Martín-Ugedo et al. (2019) using a sample of 1,393 firm-year observations drawn from Italy and Spain. They found that the presence of female on the board has a positive influence on the performance of Italian and Spanish companies. Furthermore, Jyothi \& Mangalagiri (2019) show that female directors create a positive and significant impact on the company performance as measured by ROA and Tobin's Q. They further found that the relationship becomes stronger if the company belongs to the business group. Likewise, Dang et al. (2019) investigated the relationship between women directors and performance of firms listed on the S\&P 500 over the period 2004-2015, and found a positive correlation between the presence of females on corporate boards and firm profitability (measured by the ROA).

Although many studies support the presence of female board member on the board because of its positive effect on the company's performance, others do not agree on these results, for example, in a recent study, Shehata et al. (2017) tested the association between board diversity (gender and age) and firm performance measured by accounting measure, using a sample of 34,798 small- and medium-sized enterprises (SMEs) located in the UK for the period 2005 to 2013. They conclude that each of age diversity and gender diversity have negative impact on firm ROA. Their findings also suggest that women's inclusion in boards of directors should be carefully observed and should be based on qualifications and expertise to keep away from the negative impact of financial performance.

In the USA, Adams and Ferreira (2009) also investigated the impact of board diversity, including gender on governance and performance. They used data from S\&P 500 for period 1996 to 2003, and found the negative effect of female in boardroom on market valuation and operating performance in companies that otherwise have great protect of shareholders right (strong governance), while has a positive effect in companies have weak governance. They also highlighted that the higher gender diversity of the board may reduce shareholder value related to additional monitoring. In the UK, Ahmad et al. (2018) examined the association between female director and performance using 154 firms listed on the London Stock Exchange of the FTSE 350 Index, and concluded no significant effect on financial performance. Similar findings were reported by prior studies in Norway and Sedwen. For example, Du Rietz and Henrekson (2000) found a negative relationship between firms with women on the board and performance. Examining the Norwegian firms, Bohren and Strom (2010) conclude that the existence of female board membership 
in firms seems to underperform. Finally, a third stream of studies failed to find any significant relationship between female members and corporate performance (see, e.g. Carter et al., 2010; Chapple and Humphrey, 2014; Farrell and Hersch, 2005; Randoy et al., 2006; Zahra \& Stanton, 1988). Consistent with other studies, Ross (2007) finds the same results; he argues that female members usually do not have a business background and were likely to follow male members on the board. Recently, Shabbir (2018) tested the relationship between women on corporate boards and firm performance measured by market-based measure (Tobin's Q), using a sample of 271 of Italian companies listed on the Milan Stock Exchange during 2012-2014. He found that the presence of women on corporate board does not influence firm performance. Shabbir (2018) argued that nearly two-third of the Italian companies is family-controlled. Therefore, companies appoint women in the board or for family reasons or just for respecting the law without taking into account their qualifications and skills.

However, the existing literature has not sufficiently studied the impact of female member on family business boards. Based on study of 327 Italian family firms during the period 2003 to 2007, Menozzi et al. (2015) suggests that board diversity in general is an important factor to improve decision-making and positively affect firm performance (ROA). In particular, the presence of female member on the board reveals the company strongest economic sign. Similarly, Amore et al (2014), using 2,400 median and large family-controlled firms for the period 2000-2010, and found a positive significant relationship between female directors and performance of family firms measured by ROA. Ruigrok et al. (2007) used data from Swiss family firms; found that female directors are closely related to the company's management through family ties. Lastly, using a sample of Portuguese firms listed on the Euronext Lisbon exchange between 2002 and 2013. Vieira (2018) suggest that an increase in the percentage of women on the board can increase family firm performance.

In the light of the above arguments the relationship between female directors and financial performance has been reviewed in both developed and developing countries. At the same time, however, the impact of gender diversity on corporate performance remains comparatively under-researched in Middle East countries and in particular, Jordan. The Jordanian business environment has distinctive features in terms of culture, religion and the structure of ownership, which differ to a great extent from other countries. These characteristics are expected to have a straight effect on the board of directors' practices in Jordanian companies, and thus the results of earlier studies conducted in developed or emerging countries cannot be generalized to the Jordanian firms' context. Therefore, this study focuses on the condition in Jordan. A report of IFC (2015) shows that around 3\% of board members in Jordanian companies are women. Thus, females are usually considered to be a minority group on the boards. That is, the presence of one or two female directors will not significantly affect corporate performance because their ideas and voices might be ignored by the male directors (dominant group). Accordingly, female board members are more likely to follow male members on the board. As such, female directors in Jordan are not expected to improve the firms performance, instead, they are expected to worsen it especially because they usually do not have any business background and appointed based on nepotism concerns. Given this, we postulate that the presence of female directors on the boards of Jordanian firms has no effect on their financial performance. Thus, the following hypothesis becomes:

Hypothesis 1. There is no significant relationship between female board members and Jordanian firms' performance.

\section{Sample and Data}

This research employs data that includes board variables, firm characteristics and financial performance measures of a sample of Jordanian firms listed on the ASE over the period that ranges from 2009 to 2015. The sample covers all firms that have been part of the ASE during the period. Both family and non-family firms have been included in the sample of Jordanian companies listed on the Amman Stock Exchange (ASE). Initially, 228 companies were listed on the ASE as of 31 December, 2015. Consistent with previous studies in the area of corporate governance and corporate performance (see, e.g., Anderson and Reeb, 2003; Al-Fayoumi et al., 2010 Claessens et al., 2002), financial companies have been dropped from the sample because they are subject to a strict set of regulations and different from companies in other sectors (Abed et al., 2012), and their unique features of financial statement and reporting rules makes these firms incomparable with those of other companies (Chtourou et al., 2008).

After excluding the financial companies, the data used in this study have been subjected to the following criteria: First, we exclude companies from the sample if any of the independent variables needed for the analysis are missing from annual reports that obtained either through ASE official website, the SDC archives, the companies' websites or Thomson One database. Second, companies that did not survive on ASE for less than the study period (2009 to 2015) were dropped from the sample. This selection procedure reduced the sample from 277 to 103 of 721 firm-year observations during the period 2009-2015 (representing 77.19 per cent of sample to non-financial firms). 


\subsection{Defining Family Firms}

Following La Porta et al. (1999) and Claessens et al. (2000), firms are known as family firm in this study if two or more family members are collectively identified as the largest shareholders of the firm and own at least a $10 \%$ equity stake of the company. However, in some cases the largest owner is just an individual, so we investigate whether there is another individual with the same family name on the board of directors. In these cases, we can assure that at least two members of the same family are involved in the company and therefore consider it as being family firm. Based on this definition, 56 family firms and 47 non-family firms were selected for this study, and provide 392 family firm-year observations.

\subsection{Firm Performance Measurements}

In this study, we used accounting- based measures such as the Return on Asset (ROA), which is the ratio of net income divided by the total assets. In addition, market- based measures such as Tobin's Q, which is the ratio of the book value of total assets minus the book value of equity, plus the market value of equity to the book value of assets. Most of the previous studies have used Tobin's Q and ROA as proxies for corporate financial performance (e.g., Anderson and Reeb, 2003; Denis \& Denis 1994).

\subsection{Control Variables}

One of the most important governance mechanisms is the board size. This is because the commitment and participation of board in company affairs and activities. This variable is included as control variables in our study. Guest (2009) argues that board has a strong negative impact on profitability. In addition, the negative relation is strongest for large firms, which tend to have larger boards. This view is opposed from view of Bermig \& Frick (2010) as they provide evidence that there is a positive relationship between board size and Tobin's Q. Secondly, firm size has been taken as second control variable. This variable is measured by the natural logarithm of the total assets of a firm. All variables used in this study are defined in Table 1.

Table 1. Variables definitions

\begin{tabular}{ll}
\hline Variables & Definitions \\
\hline FEMBOD & The total number of female directors on the board. \\
\hline ROA & (Net Income / Total Assets) $\times 100$ \\
\hline Tobin's $\boldsymbol{Q}$ & Market value of the firm / Total assets \\
\hline FSIZE & Log (Total Assets) \\
\hline BODSIZE & The total number of directors on board \\
\hline
\end{tabular}

\section{Methodology}

The current study employs a multivariate pooled OLS regression to empirically examine the potential relationship between female board members and financial performance for both family and non-family firms. . Thus, the following model has been adopted:

Firm Performance $=\mathrm{f}($ Female board member, Board size, Firm size $)$

That is,

$$
F P=\alpha+\beta 1 F E M B O D+\beta 2 B O D S I Z E+\beta 3 F S I Z E+\varepsilon
$$

Where, FP is the firm performance measured by either the ROA or Tobin's Q; ROA, is the return on assets measured by the net income divided by the total assets, Tobin's Q is the market value of equity divided by its book value, FEMBOD is the female presentation on the bard measured by the number of female directors on the board, BODSIZE, is the size of the board measured by total number of directors on board, FSIZE is the firm size measured by the natural logarithm of total assets.

\section{Findings}

\subsection{Descriptive Statistics}

This section provides the descriptive statistics for the dependent, independent and control variables used to test our hypothesis. Table 2 is divided into two panels: Panel A shows the mean, min, max and standard deviation values, for 
the full sample variables across the five-year sample period. Whereas Panel B reports the descriptive statistics for these variables after splitting the full sample into two sub-samples namely, family and non-family sample firms.

As can be seen from Panel A in Table 2, on average, 28\% of directors are female members, with a minimum of 0 and a maximum of 2 members on the board. The report of IFC (2015) shows that among 237 public listed companies in 2012, only 52 firms having women on their board, which means that 3.54 percent of board members in Jordanian companies are women (World Bank Group, 2015). Therefore, it can be noted that the female representation in Jordanian companies has been improved. The statistics reveal that the mean board size for the whole sample of the 103 listed Jordanian companies is 8.14, with a minimum of 5 and a maximum of 13 members on the board. The table also shows that the minimum value of ROA is $-17.3 \%$ while the highest value is close to $14 \%$ with an average of $2.92 \%$ for the whole sample. With regards to Tobin's Q, our figures show that the minimum value of Tobin's $Q$ is -0.0128 while the highest value is 0.058 with an average of 0.017 for the overall sample firms. The average of total assets is $69,260,717$, ranging from a minimum of 4,698,481 million to a maximum of $176,578,43$ million.

Table 2. Descriptive statistics

Panel A. The full sample

\begin{tabular}{lllll}
\hline Variables & Mean & Min & Max & Std. Dev. \\
\hline FEMABO & 0.282 & 0 & 2 & 0.560 \\
\hline ROA & 2.92 & -17.3 & 13.6 & 5.29 \\
\hline Tobin's Q & 0.017 & -0.0128 & 0.058 & 0.033 \\
\hline BOSIZE & 8.14 & 5 & 13 & 2.201 \\
\hline TA(\$ Millions) & 69,260 & 4,698 & 176,578 & 8758538 \\
\hline
\end{tabular}

Panel B of Table 2 shows that the mean for the board size (BOSIZE) for family firm is slight different from non-family firms, 7.94 and 8.37 respectively. The reason behind the small size of the board of family firms is that family firms prefer smaller boards since the individual commitments are subject to dispersion in larger boards (Ward, 1991). The figures also show a difference in the means of female board members between family firms and nonfamily firms, $31.8 \%$ and $24 \%$ respectively. The mean differences are statistically significant at the $10 \%$ level. The founders appointing their daughters and wives on the boards might cause the higher FEMABO in family firms. Since their appointment is consistent with the increased demand for family dominance (Boubaker et al., 2016). Table (3) also reveals that non-family firms on average are slight larger in size, as measured the logarithm of the total assets, compared to family firms. The mean difference for non-family firms and family firms are statistically significant at the $1 \%$ level.

Panel B. Independent t-test (family and non-family firms)

\begin{tabular}{lllll}
\hline Variables & Mean & \multicolumn{2}{c}{ Diff-Mean } & Sig (2Tailed) \\
\cline { 2 - 3 } & Family Firms & Non-Family Firms & \\
\hline BOSIZE & 7.949 & 8.379 & 0.431 & $0.008^{* *}$ \\
\hline FEMABO & 0.318 & 0.240 & -0.078 & $0.060^{*}$ \\
\hline FSIZE & 7.224 & 7.514 & 0.290 & $0.00^{* *}$ \\
\hline ROA (\%) & 0.049 & 0.582 & 0.533 & 0.178 \\
\hline Tobin's Q & -0.012 & 0.532 & 0.0659 & $0.00^{* *}$ \\
\hline
\end{tabular}

\subsection{Multivariate Analysis}

In all tables, the results are jointly significant at $1 \%, 5 \%$ and $10 \%$ of significance. It should be noted that R-squares for the ROE range from 5\% to $38 \%$ for family and non-family firms. For family firms, based on both the accounting 
measure (ROA) and the market measure (Tobin's Q), our findings show that there is an insignificant relationship between female board members and corporate performance. This finding consistent with our expectation in (Hypothesis 1), which stated that there is no relationship between female board member and Jordanian firms' performance. However, our finding is consistent with some studies that also failed to find any significant relationship between female members and corporate performance (e.g., Carter et al., 2010; Chapple and Humphrey, 2014; Rose, 2007; Randoy et al., 2006; Zahra \& Stanton, 1988). In fact, the presence of female members of Jordanian family boards is relatively low (less than two) compared with male directors, so their impact on the board might be limited. A possible explanation presented by Bear et al. (2010) was that one single female might face difficulties to get their ideas heard because minority group members are often ignored. Therefore, Joecks et al. (2013) argued that female directors may initially affect the company negatively, and not before the board is composed of about $30 \%$ of women, the impact will be reflected and associated with improved financial performance compared to boards that only consisted of men. They conclude that the high gender diversity on the board has led to benefits for the effectiveness of the board, but the mere presence of one woman on the board was not varied enough to affect corporate performance. According to Liu et al. (2013) boards with more than three woman directors have a significant influence on the performance of a firm.

Table 3. The impact of female directors on firm performance measured by the ROA

\begin{tabular}{lllll}
\hline ROA & \multicolumn{3}{l}{ Non-family Firms } \\
\hline Variables & Coef. & P(Sig) & Coef. & P(Sig) \\
\hline BOSIZE & -0.024 & $0.021^{* *}$ & 0.121 & 0.786 \\
\hline FEMABO & 0.007 & 0.315 & -0.139 & $0.079^{*}$ \\
\hline FSIZE & 0.018 & 0.121 & 0.382 & $0.000^{* * *}$ \\
\hline
\end{tabular}

Table 4. The impact of female directors on firm performance measured by Tobin's Q

\begin{tabular}{lllll}
\hline Tobin's Q & \multicolumn{5}{l}{ Non-family Firms } \\
\hline Variables & Coef. & $\mathrm{P}(\mathrm{Sig})$ & Coef. & $\mathrm{P}(\mathrm{Sig})$ \\
\hline BOSIZE & -0.075 & $0.034^{* *}$ & 0.350 & 0.234 \\
\hline FEMABO & -0.406 & 0.379 & -0.377 & $0.016^{* *}$ \\
\hline FSIZE & 0.087 & 0.891 & -0.096 & 0.102 \\
\hline
\end{tabular}

Regarding non-family firms, the results show that there is a significant negative relationship between the presence of female on the board and corporate performance (as measured by the ROA or Tobin's Q). Based on this finding, the hypothesis (H1) for non-family firms, which stated that there is no relationship between female board member and financial performance as measured by ROA or Tobin's Q, is rejected. However, the findings is consistent with the results reported by previous studies such as Adams and Ferreira (2009), Bohren and Strom (2010), Shehata et al. (2017) which conclude that gender diversity have negative impact on firm performance. Their findings also suggest that women's inclusion in boards of directors should be carefully observed and should be based on qualifications and expertise to keep away from the negative impact of financial performance.

\section{Conclusion}

The present paper examines the impact of female directors on the performance of family and non-family Jordanian firms. For the purpose of this study, we differentiate between family and non-family firms. The firm performance is measured by two measures, namely the return on assets (ROA) and Tobins Q. Using panel data from 103 Jordanian public firms over the 2009-2015 periods, the empirical results reveal that, for family firms, female directors do not have any significant impact on firm performance. Whereas for non-family firms, female directors appeared have a significant negative impact on the firm performance. This is not surprising because females are usually considered to be a minority group on the boards of Jordanian firms. That is, the presence of one or two female directors will not 
significantly affect corporate performance because their ideas and voices might be ignored by the male directors (dominant group). Also, various cultural factors may influence the impact of female directors. For example, the view of many Jordanians is that the role of women must be limited to family and household and must not extend to the business world and the workplace. Further, some Jordanian families put enormous pressure on young professional women, preventing them from working long hours, encouraging them not to take evening shifts, and so on, which hinders them from taking on more responsibilities and reaching higher management levels. Some professional women who reach middle management sometimes have to leave their posts because of family or social pressures (Jordan Department of Statistics 2013).

Rather than providing final conclusion, this study should be considered a useful starting point for further research. It would be interesting to investigate the involvement of female in the firm more directly through studies based on case studies, interviews, and questionnaire surveys. This can deepen our understanding of the impact of Jordanian female directors on issues such as their actual roles and responsibilities in the board.

This finding tells us that it is unwise to assume good performance when Jordanian board comprised of female directors in the corporate sector. Our findings are useful for various parties, such as regulators and policy makers. For regulators, this research may contribute to gender representation in policies for boards through imposing laws and recommendations on gender diversity on the boards, the Jordanian government should induce all firms to appoint a number of female directors on the board. This regulation would effectively encourage Jordanian listed firms in appointing female directors. This research also can build awareness on the contribution of women to the firms and encourage women with good skills and qualifications to be appointed. This research also recommends firms to run women's career development programs periodically.

Like all research, this study is subject to limitations that it is important to recognise. First, this study examines only non-financial firms listed on the Amman Stock Exchange. This limitation reduces the size of the sample from 228 to 103. Thus, the findings of this study cannot be generalised to financial firms. In addition, it is difficult to generalise to other countries which are dissimilar to Jordan, which has it is own culture and regulations. Therefore, researchers could usefully make a comparison between firms and countries. Second, the sample period ends in 2015, while future research could include later periods.

\section{Acknowledgement}

The authors are grateful to the Middle East University, Amman, Jordan for the financial support granted to cover the publication fee of this research article.

\section{References}

Abed, S., Al-Attar, A., \& Suwaidan, M. (2012). Corporate Governance and Earnings Management: Jordanian Evidence. International Business Research, 5(1), 216. https://doi.org/10.5539/ibr.v5n1p216

Adams, R. B., \& Ferreira, D. (2009). Women in the boardroom and their impact on governance and performance. Journal of Financial Economics, 94(2), 291-309. https://doi.org/10.1016/j.jfineco.2008.10.007

Ahern, K. R., \& Dittmar, A. K. (2012). The changing of the boards: The impact on firm valuation of mandated female board representation. The Quarterly Journal of Economics, 127(1), 137-197. https://doi.org/10.1093/qje/qjr049

Ahmad, N., Naveed, A., \& Fazal, A. (2018). An Empirical Analysis of Boardroom Diversity on Firm Performance. Review of Economics \& Finance, 13, 62-76.

Al-Fayoumi, N., Abuzayed, B., \& Alexander, D. (2010). Ownership Structure and Earnings Management in Emerging Markets: The Case of Jordan. International Research Journal of Finance and Economics, 38, 28-47.

Al-Matari, E., Al-Swidi, A., Fadzil, F., \& Al-Matari, Y. (2012). The impact of board characteristics on firm performance: Evidence from nonfinancial listed companies in Kuwaiti Stock Exchange. International Journal of Accounting and Financial Reporting, 2(2), 310-332. https://doi.org/10.5296/ijafr.v2i2.2384

Alves, P., Couto, E. B., \& Morais Francisco, P. (2015). Board of Directors composition and capital structure. Research in International Business and Finance, 35, 1-32. https://doi.org/10.1016/j.ribaf.2015.03.005

Amore, M. D., Garofalo, O., \& Minichilli, A. (2014). Gender Interactions within the Family Firm. Management Science, 60(5), 1083-1097. https://doi.org/10.1287/mnsc.2013.1824

Anderson, R. C., \& Reeb, D. M. (2003). Founding-Family Ownership and Firm Performance: Evidence from the S\&P 500. The Journal of Finance, 58(3), 1301-1327. https://doi.org/10.1111/1540-6261.00567 
Anderson, R. C., Reeb, D. M., Upadhyay, A., \& Zhao, W. (2011). The economics of director heterogeneity. Financial Management, 4O(1), 5-38. https://doi.org/10.1111/j.1755-053X.2010.01133.x

Arfken, D. E., Bellar, S. L., \& Helms, M. M. (2004). The ultimate glass ceiling revisited: The presence of women on $\begin{array}{lllll}\text { corporate boards. Journal of Business } & \text { Ethics, } & \text { 50(2), }\end{array}$ https://doi.org/10.1023/B:BUSI.0000022125.95758.98

Barney, J. (1991). Firm resources and sustained competitive advantage. Journal of Management, 17(1), 99-120. https://doi.org/10.1177/014920639101700108

Bear, S., Rahman, N., \& Post, C. (2010). The impact of board diversity and gender composition on corporate social responsibility and firm reputation. Journal of Business Ethics, 97(2), 207-221. https://doi.org/10.1007/s10551-010-0505-2

Belenky, M. F., Clinchy, B. M., Goldberger, N. R., \& Tarule, J. M. (1986). Women's Ways of Knowing. Basic Books, NY.

Bermig, A., \& Frick, B. (2010). Board size, board composition, and firm performance: Empirical evidence from Germany. https://doi.org/10.2139/ssrn.1623103

Bilimoria, D. (2006). The relationship between women corporate directors and women corporate officers. Journal of Managerial Issues, 47-61.

Bohren, O., \& Strom, R. O. (2010). Governance and politics: Regulating independence and diversity in the board room. Journal of Business Finance \& Accounting, 37(9-10), 1281-1308. https://doi.org/10.1111/j.1468-5957.2010.02222.x

Bonn, I., Yoshikawa, T., \& Phan, P. H. (2004). Effects of board structure on firm performance: A comparison between Japan and Australia. Asian Business \& Management, 3(1), 105-125. https://doi.org/10.1057/palgrave.abm.9200068

Boubaker, S., Nguyen, P., \& Rouatbi, W. (2016). Multiple Large Shareholders and Corporate Risk-taking: Evidence from French Family Firms. European Financial Management, 22(4), 697-745. https://doi.org/10.1111/eufm.12086

Brennan, N. (2006). Boards of directors and firm performance: is there an expectations gap?. Corporate Governance: An International Review, 14(6), 577-593. https://doi.org/10.1111/j.1467-8683.2006.00534.x

Burgess, Z., \& Tharenou, P. (2002). Women board directors: Characteristics of the few. Journal of Business Ethics, 37(1), 39-49. https://doi.org/10.1023/A:1014726001155

Campbell, K., \& Mínguez-Vera, A. (2008). Gender diversity in the boardroom and firm financial performance. Journal of Business Ethics, 83(3), 435-451. https://doi.org/10.1007/s10551-007-9630-y

Carter, D. A., D'Souza, F., Simkins, B. J., \& Simpson, W. G. (2010). The gender and ethnic diversity of US boards and board committees and firm financial performance. Corporate Governance: An International Review, 18(5), 396-414. https://doi.org/10.1111/j.1467-8683.2010.00809.x

Carter, D. A., Simkins, B. J., \& Simpson, W. G. (2003). Corporate governance, board diversity, and firm value. Financial Review, 38(1), 33-53. https://doi.org/10.1111/1540-6288.00034

Catalyst. (2004). The Bottom Line: Connecting Corporate Performance and Gender Diversity. New York: Catalyst.

Chapple, L., \& Humphrey, J. E. (2014). Does board gender diversity have a financial impact? Evidence using stock portfolio performance. Journal of Business Ethics, 122(4), 709-723. https://doi.org/10.1007/s10551-013-1785-0

Chtourou, S. M., Bedard, J., \& Courteau, L. (2008). Corporate governance and earnings management. Working Paper, University of Laval Canada.

Claessens, S., Djankov, S., \& Lang, L. H. (2000). The Separation of Ownership and Control in East Asian Corporations. Journal of Financial Economics, 58(1), 81-112. https://doi.org/10.1016/S0304-405X(00)00067-2

Claessens, S., Djankov, S., Fan, J. P., \& Lang, L. H. (2002). Disentangling the Incentive and Entrenchment Effects of Large Shareholdings. The Journal of Finance, 57(6), 2741-2771. https://doi.org/10.1111/1540-6261.00511

Cole, P. M. (1997). Women in Family Business. Family Business Review, 10(4), 353-371. https://doi.org/10.1111/j.1741-6248.1997.00353.x

Corbetta, G., \& Salvato, C. A. (2004). The board of directors in family firms: one size fits all?. Family Business 
Review, 17(2), 119-134. https://doi.org/10.1111/j.1741-6248.2004.00008.x

Cox, T. H., \& Blake, S. (1991). Managing cultural diversity: Implications for organizational competitiveness. The Executive, 45-56. https://doi.org/10.5465/ame.1991.4274465

Cromie, S. Y., \& Sullivan, S. (1999). Women as managers in family business. Women Management Review, 14, 76-88. https://doi.org/10.1108/09649429910269884

Daily, C. M., Certo, S. T., \& Dalton, D. R. (1999). A decade of corporate women: Some progress in the boardroom, none in the executive suite. Strategic Management Journal, 93-99. https://doi.org/10.1002/(SICI)1097-0266(199901)20:1<93::AID-SMJ18>3.0.CO;2-7

Daily, C., \& Dalton, D. (1994). Bankruptcy and corporate governance: The impact of board composition and structure. Academy of Management Journal, 37(6), 1603-1617. https://doi.org/10.2307/256801

Dang, R., Houanti, L'H., Reddy, K., \& Simioni, M. (2019). Does board gender diversity influence firm profitability? A control function approach. Working Papers of LaRGE Research Center 2019-01, Laboratoire de Recherche en Gestion et Economie (LaRGE), Université de Strasbourg.

Dauer, U. (2014). Corporate Germany Set for Gender Revolution. Wall Street Journal. Retrieved 26 May 2018, from http://www.wsj.com/articles/german-cabinet-gives-nod-to-increase-number-of-women-on-boards-1418299350

Davies, E. M. (2012). The Davies Report: Women on Boards.

Denis, D. J., \& Denis, D. K. (1994). Majority owner-managers and organizational efficiency. Journal of Corporate Finance, 1(1), 91. https://doi.org/10.1016/0929-1199(94)90011-6

Du Rietz, A., \& Henrekson, M. (2000). Testing the female underperformance hypothesis. Small Business Economics, 14(1), 1-10. https://doi.org/10.1023/A:1008106215480

Erhardt, N. L., Werbel, J. D., \& Shrader, C. B. (2003). Board of director diversity and firm financial performance. Corporate Governance: An International Review, 11 (2), 102-111. https://doi.org/10.1111/1467-8683.00011

Farrell, K. A., \& Hersch, P. L. (2005). Additions to corporate boards: the effect of gender. Journal of Corporate Finance, 11(1-2), 85-106. https://doi.org/10.1016/j.jcorpfin.2003.12.001

Fenwick, G. D., \& Neal, D. J. (2001). Effect of gender composition on group performance. Gender, Work \& Organization, 8(2), 205-225. https://doi.org/10.1111/1468-0432.00129

Ferreira, D. (2015). Board diversity: Should we trust research to inform policy?. Corporate Governance: An International Review, 23(2), 108-111. https://doi.org/10.1111/corg.12092

Francoeur, C., Labelle, R., \& Sinclair-Desgagné, B. (2008). Gender diversity in corporate governance and top management. Journal of Business Ethics, 81(1), 83-95. https://doi.org/10.1007/s10551-007-9482-5

Gilligan, C. (1982). In a different voice: Psychological theory and women's development. Cambridge, MA: Harvard University Press.

Green, C. P., \& Homroy, S. (2018). Female directors, board committees and firm performance. European Economic Review, 102, 19-38. https://doi.org/10.1016/j.euroecorev.2017.12.003

Guest, P. M. (2009). The impact of board size on firm performance: evidence from the UK. The European Journal of Finance, 15(4), 385-404. https://doi.org/10.1080/13518470802466121

Harrison, R. T., \& Leitch, C. M. (1996). Discipline Emergence in Entrepreneurship: Accumulative Fragmentalism or Paradigmatic Science?. Entrepreneurship, Innovation, and Change, 5(2), 65-83.

Hillman, A., \& Dalziel, T. (2003). Boards of directors and firm performance: Integrating agency and resource dependence perspectives. Academy of Management Review, 28(3), 383-385. https://doi.org/10.5465/amr.2003.10196729

Huse, M. (2007). Boards, governance and value creation: The human side of corporate governance. Cambridge, UK: Cambridge University Press. https://doi.org/10.1017/CBO9780511611070

Ibarra, H. (1993). Personal networks of women and minorities in management: A conceptual framework. Academy of Management Review, 18(1), 56-87. https://doi.org/10.5465/amr.1993.3997507

IFC Family Business Governance Handbook. (2011). Washington, D.C.: International Finance Corporation.

Jimenez, R. M. (2009). Research on women in family firms current status and future directions. Family Business 
Review, 22(1), 53-64. https://doi.org/10.1177/0894486508328813

Joecks, J., Pull, K., \& Vetter, K. (2013). Gender diversity in the boardroom and firm performance: What exactly constitutes a "critical mass?". Journal of Business Ethics, 118(1), 61-72. https://doi.org/10.1007/s10551-012-1553-6

Jordan Department of Statistics. (2013). Percentage distribution of Jordanian females aged 15 years and above by economic activity status and marital status. Table. Jordan Department of Statistics.

Jyothi, P., \& Mangalagiri, J. (2019). Would Firm Performance Be Better With Women Directors? Evidence From India. https://doi.org/10.1177/0972262919840217

La Porta, R., Lopez de Silanes, F., Shleifer, A., \& Vishny, R. (1999). Investor Protection and Corporate Valuation. Nber Working Paper Series, No. 7403. https://doi.org/10.3386/w7403

Liu, Y., Wei, Z. B., \& Xie, F. X. (2013). Do Women Directors Improve Firm Performance in China. Journal of Corporate Finance, 28, 169-184. https://doi.org/10.1016/j.jcorpfin.2013.11.016

Luoma, P., \& Goodstein, J. (1999). Stakeholders and corporate boards: Institutional influences on board composition and structure. Academy of Management Journal, 42(5), 553-563. https://doi.org/10.2307/256976

Martín-Ugedo, J. F., \& Minguez-Vera, A. (2014). Firm performance and women on the board: Evidence from Spanish small and medium-sized enterprises. Feminist Economics, 20(3), 136-162.

Martín-Ugedo, J. F., Mínguez-Vera, A., \& Rossi, F. (2019). Female directors and firm performance in Italian and Spanish listed firms. Academia Revista Latinoamericana de Administración.

McVey, H., \& Draho, J. (2005). US Family-Run Companies-They May Be Better Than You Think. Journal of Applied Corporate Finance, 17(4), 134-143. https://doi.org/10.1111/j.1745-6622.2005.00067.x

Menozzi, A., Fraquelli, G., \& Novara, J. D. (2015). Board diversity in family firms.

Moore, S., Grunberg, L., \& Greenberg, E. (2005). Are female supervisors good for employee job experiences, health, and wellbeing?. Women in Management Review, 20(2), 86-95. https://doi.org/10.1108/09649420510584427

Nekhili, M., \& Gatfaoui, H. (2013). Are demographic attributes and firm characteristics drivers of gender diversity? Investigating women's positions on French boards of directors. Journal of Business Ethics, 118(2), 227-249.

Nguyen, H., \& Faff, R. (2007). Impact on board size and board diversity on firm value: Australian evidence. Corporate Ownership \& Control, 4(2), 24-32. https://doi.org/10.22495/cocv4i2p2

Nicholson, G. J., \& Kiel, G. C. (2007). Can directors impact performance? A case-based test of three theories of corporate governance. Corporate Governance: An International Review, 15(4), 585-608.

Nielsen, S., \& Huse, M. (2010). The contribution of women on boards of directors: Going beyond the surface. Corporate Governance: An International Review, 18(2), 136-148.

Pandya, H. (2011). Corporate governance structures and financial performance of selected Indian banks. Journal of Management \& Public Policy, 2(2), 4-21.

Parola, H. R., Ellis, K. M., \& Golden, P. (2015). Performance effects of top management team gender diversity during the merger and acquisition process. Management Decision, 53(1), 57-74.

Pearce, J. A., \& Zahra, S. A. (1992) .Board Composition from a Strategic Contingency Perspective. Journal of Management Studies, 29(4), 411-438. https://doi.org/10.1111/j.1467-6486.1992.tb00672.x

Pfeffer, J. (1972). Size and composition of corporate boards of directors: The organization and its environment. Administrative Science Quarterly, 17(2), 218- 228. https://doi.org/10.2307/2393956

Post, C., \& Byron, K. (2015). Women on boards and firm financial performance: A meta-analysis. Academy of Management Journal, 58(5), 1546-1571. https://doi.org/10.5465/amj.2013.0319

Randoy, T., Thomsen, S., \& Oxelheim, L. (2006). A Nordic perspective on corporate board diversity. Working Paper, Agder University College, Norway.

Reguera-Alvarado, N., de Fuentes, P., \& Laffarga, J. (2017). Does board gender diversity influence financial performance? Evidence from Spain. Journal of Business Ethics, 141(2), 337-350.

Rose, C. (2007). Does female board representation influence firm performance? The Danish evidence. Corporate Governance: An International Review, 15(2), 404-413. https://doi.org/10.1111/j.1467-8683.2007.00570.x 
Ruigrok, W., Peck, S., \& Tacheva, S. (2007). Nationality and Gender Diversity on Swiss Corporate Boards. Corporate Governance: An International Review, 15(4), 546-557.

Salganicoff, M. (1990). Women in Family Businesses: Challenges and Opportunities. Family Business Review, 3(2), 125-137. https://doi.org/10.1111/j.1741-6248.1990.00125.x

Sarkar, J., \& Selarka, E. (2015). Women on board and performance of family firms: Evidence from India.

Scheme. (2013). Corporate social responsibility and gender in the workplace: A study of selected Jordanian private sector companies. Scheme Tactical Thinking Report. Retrieved from http://schemaadvisory.com/wp-content/uploads/2014/12/CIDA-Final-Short.pdf

Schwartz, S. H. (1992). Universals in the Context and Structure of Values: Theoretical Advances and Empirical Tests in 20 Countries. In M. P. Zana (Ed.), Advances in Experimental Social Psychology.

Shabbir, M. S. (2018). Women on Corporate Boards and Firm Performance, Preliminary Results from Italian Listed Companies after the Introduction of Gender Quota Law 120/2011. Journal of Business \& Financial Affairs, 7 , 316.

Shehata, N., Salhin, A., \& El-Helaly, M. (2017). Board diversity and firm performance: evidence from the UK SMEs. Applied Economics, 49(48), 4817-4832. https://doi.org/10.1080/00036846.2017.1293796

Sing, J. V., House, R. J., \& Tucker, D. J. (1986). Organizational change and organizational mortality. Administrative Science Quarterly, 31(4), 587-611. https://doi.org/10.2307/2392965

Smith, N., Smith, V., \& Verner, M. (2006). Do women in top management affect firm performance? A panel study of 2,500 Danish firms. International Journal of Productivity and Performance Management, 55(7), 569-593.

Songini, L., \& Gnan, L. (2015). Family Involvement and Agency Cost Control Mechanisms in Family Small and Medium-Sized Enterprises. Journal of Small Business Management, 53(3), 748-779.

Srinidhi, B., Gul, F. A., \& Tsui, J. (2011). Female directors and earnings quality. Contemporary Accounting Research, 28(5), 1610-1644. https://doi.org/10.1111/j.1911-3846.2011.01071.x

Stern, S. (2009). Successes and soap operas. Financial Times, June 1.

Stern, S. (2014). Men in Skirts' Do Not Enhance Diversity. Financial Times: Executive Appointment, April 3, p. 3.

The UK Corporate Governance Code. (2014). Retrieved from https://www.frc.org.uk/Our-Work/Publications/Corporate-Governance/UK-Corporate-Governance-Code-2014.p df

Torchia, M., Calabrò, A., \& Morner, M. (2015). Board of directors' diversity, creativity, and cognitive conflict: The role of board members' interaction. International Studies of Management \& Organization, 45(1), 6-24.

United States Department of Labor (USDOL). (2005). Women in the Labor Force: ADatebook.

Vafaei, A., Mather, P., \& Ahmed, K. (2012). Board gender diversity and its effect on firm financial performance: A panel study of top 500 ASX listed firms. Working Paper. https://doi.org/10.2139/ssrn.2029140

Vieira, E. S. (2018). Board of directors characteristics and performance in family firms and under the crisis. Corporate Governance: The International Journal of Business in Society, 18(1), 119-142.

Ward, J. L. (1991). The Active Board with Outside Directors and the Family Firm. Family Business Review, 1(3), 223-229. https://doi.org/10.1111/j.1741-6248.1988.00223.x

Watson, W. E., Kumar, K., \& Michaelsen, L. K. (1993). Cultural diversity's impact on interaction process and performance: Comparing homogeneous and diverse task groups. Academy of Management Journal, 36(3), 590-602. https://doi.org/10.2307/256593

Williams, R. J. (2003). Women on corporate boards of directors and their influence on corporate philanthropy. Journal of Business Ethics, 42(1), 1-10. https://doi.org/10.1023/A:1021626024014

Women and Equality Unit (WEU). (2002). Key Indicators of Women's Position in Britain.

World Bank Group. (2015). “Gender.” Enterprise Survey. Washington, D.C.: World Bank Group. Retrieved from http://www.enterprisesurveys.org/Data/ExploreTopics/gender

Zahra, S., \& Stanton, W. (1988). The implications of board of directors' composition for corporate strategy and performance: A review and integrative model. International Journal of Management, 15(2), 229-236. 